\title{
Antiviral Impact of Melatonin with Reference to Influenza Virus and Covid-19 Infection
}

\section{Seema Rai* and Suman Rathore}

Department of Zoology, Guru Ghasidas Vishwavidyalaya, Bilaspur, Chhattisgarh, India

*Corresponding Author: Seema Rai, Department of Zoology, Guru Ghasidas Vishwavidyalaya, Bilaspur, Chhattisgarh, India.
Received: June 20, 2021

Published: July 13, 2021

(C) All rights are reserved by Seema Rai and

Suman Rathore.

\begin{abstract}
Melatonin has long been considered to play a crucial role in our interactions with viruses. Influenza, sometimes known as the flu, is an RNA virus-borne infectious illness to play a crucial role in our interactions with viruses. Influenza, sometimes known as the flu, is an RNA virus-borne infectious illness TNF- $\alpha$, IL-6, and IFN- $\gamma$ are inflammatory cytokines. IFN- $\gamma$ inhibits the viral infection. Melatonin therapy dramatically reduces TNF- $\alpha$, IL- 6 , and IFN- $\gamma$ expression while increasing IL- 10 and TGF- $\beta$ production, according to this study. Melatonin promotes the synthesis of IL-10 by upregulating the expression of IL-27 in dendritic cells. Melatonin also decreases the levels of TNF- $\alpha$ in CD8 T cells in a considerable way. Compared to ribavirin alone, melatonin plus ribavirin co-treatment dramatically enhances the lifespan of virus-infected mice. Melatonin therapy decreases the production of inflammatory cytokines while increases the production of anti-inflammatory cytokines during influenza infection with a virus. Findings suggest that melatonin might be used as an adjuvant therapy with antiviral medications to treat influenza-induced pneumonia and COVID-19.
\end{abstract}

Keywords: COVID-19; TNF- $\alpha$; Melatonin

\section{Introduction}

Whenever the SARS-CoV-2 virus binds to ACE2 receptors in airway epithelial cells, it triggers a pro-inflammatory response that leads to a cytokine storm and the beginning of Acute Respiratory Distress Syndrome (ARSD) [1,2]. ROS-mediated damage to the alveoli is caused by an extra pro-oxidant reaction [3]. COVID-19 therapy should begin as soon as possible after diagnosis to avoid severe instances. Compounds that reduce cancer progression and oxidative damage can reduce infection morbidity and mortality [4]. Melatonin has long been considered to play a crucial role in our interactions with viruses. Influenza, sometimes known as the flu, is an RNA virus-borne infectious illness. It belongs to the orthomyxoviridae virus family, which infects birds and mammals. Influenza is the leading cause of sickness, death, and economic loss in humankind. The symptoms of this virus include chills, fever, sore throat, muscular pain, severe headache, coughing, weakness, tiredness, and overall discomfort [5]. During infections involving the H1N1 influenza virus pneumonia and severe acute lung inju- ries develop. Melatonin is produced by pinealocytes. It is an indoleamine molecule in the pineal gland in humans. Melatonin exerts anti-inflammatory, antioxidant, immunomodulatory properties $[6,7]$. Hormone drugs, such as dexamethasone and methylprednisolone [8], have proved promising. Patients treated with dexamethasone showed decreased mortality rates at 28 days compared to those treated with conventional care, according to a study conducted by the RECOVERY Collaboration Group in the United Kingdom (25.7 percent, 41.4 percent and 26.2 percent). Melatonin is a neurohormone chiefly secreted by pineal gland at night. Melatonin is generated in neurons and glial cells on occasion, contributing to the high amount of melatonin in the CSF as compared to blood concentrations. Melatonin secreted in the CSF may slow the course of neurodegenerative disorders. Viral infections can cause neurodegenerative changes and harm to the brain [9]. Viruses have evolved the ability to breach the blood-brain barrier (BBB) and impact the central nervous system (CNS), leading in neuronal surgery and degeneration [10]. Severe influenza and covid-19 infections ap- 
pear to be triggered by a "cytokine storm", with proinflammatory cytokines limiting pineal melatonin synthesis. The immune-pineal axis works by proinflammatory cytokines signalling the need for a continuing immune response, preventing it from being suppressed by pineal melatonin [11]. Based on melatonin's previously documented anti-oxidant and immunological modulatory effects, we examined its therapeutic potential in influenza virus infection in this work. High-dose melatonin pretreatment and therapy dramatically enhanced the survival of influenza virus-infected mice, as suggested by various findings [12]. Although significant in all cells sensitive to circadian control by pineal melatonin, the pineal melatonin/ mitochondrial melatonin pathway may be especially essential in immune cells. Immune cell activity throughout the day is linked to glycolytic metabolism, which is reset by pineal melatonin to OXPHOS, resulting in more quiescent immune cell phenotypes [13].

\section{Melatonin's functions in viral infection control}

Based on the findings of both in vitro and in vivo studies, melatonin supplementation can be beneficial against a variety of viral infections from various families. Melatonin has been seen to have the following effects in this context:

- $\quad$ By inhibiting viral replication processes, the antiviral effects are accomplished by lowering viral titer or new progeny development in the target tissues or cells $[14,15]$.

- The antioxidant effects reduce oxidative stress in virusinfected cells by decreasing free radical formation and lipid peroxidation. The longevity of virus-infected cells is aided by maintaining an equilibrium in redox reactions, as well as the regulatory effects of mitochondria and ER in virus-infected cells $[16,17]$.

- Anti-apoptotic effects shield cells from virus-induced apoptosis by regulating the intrinsic apoptosis mechanism, which enhances anti-apoptotic proteins while reducing pro-apoptotic proteins and caspase cascade development [18].

- $\quad$ The autophagy pathway, which aids in the removal of cellular debris from virus-infected tissues, is controlled [19].

- Immunomodulatory effects control and facilitate immune system responses in order to combat viral invasion [17].

- Anti-inflammatory effects avoid the harmful effects of proinflammatory cytokines on host cells by inhibiting the unwanted inflammatory response caused by viral infections [15,20].
Effects of selected antioxidants on the pathogenesis of viral infections

Supplementary medicines and antioxidant medications are used for more than just avoiding deficiencies and inhibiting free radical growth. Viral infections are only one of the many signs that vitamins and antioxidants could be necessary. As a result, it's impossible to overstate the significance of knowing the potential effectiveness and action of supplements and antioxidants in the treatment of viral infections, especially coronavirus disease.

\section{Melatonin}

Melatonin may be used as an adjuvant to many medications, such as antiviral medicines, during the SARS-CoV-2 crisis to improve pharmacological treatment and minimise side effects, since melatonin has been shown to minimise certain antiviral medication side effects [21,22].

\section{$\mathrm{N}$-acetyl-l-cysteine}

$\mathrm{N}$-acetyl-l-cysteine (NAC), an acetylated counterpart of the amino acid l-cysteine, is a good supply of thiol groups. It is broken down in the body into metabolites that promote glutathione (GSH) production, detoxification, and serve as direct free radical scavengers to prevent reactive oxygen species from forming. It also prevents viral replication, apoptosis, and gene expression for $\mathrm{z}$ pro-inflammatory cytokines and chemokines including interleukin (IL)-6, IL-8, RANTES, and interferon (INF)-inducing protein (IP)10 throughout influenza virus infection [23].

\section{Ascorbic acid}

Since COVID-19 is affected by a novel different genome sequence, the clinical results associated with the use of ascorbic acid can vary [24].

\section{Vitamin D}

It retains cellular natural immunity and adaptive immunity by reducing the cytokine storm and suppressing responses mediated by $\mathrm{T}$ helper cell type 1 produced by the innate immune system, which produces pro-inflammatory cytokines including tumour necrosis factor, IL-2, and IFN-gamma, which are both thought to be effective predictors of worse outcome in patients with extreme viral infections, like COVID-19 [25].

\section{Zinc}

Zinc supplementation could increase the proportion of CD4+ CD3+ cells in the peripheral blood, resulting in improved T-cellmediated immunity and increased monocyte resistance to apoptosis by suppressing caspase 3 activation. It can also cause the 
development of antiviral INF, which has antiviral properties and suppresses inflammatory events, such as those caused by the H1N1 influenza virus [26,27].

The aim of the present study is to review the therapeutic potential of melatonin during influenza or SARS-CoV-2 induced pneumonia and also to explore its adjuvant treatment with antiviral drugs.

Table 1 summaries research on the impact of melatonin on viral infections. Melatonin has a defensive effect in all tissues; for example, it acts as a strong free-radical scavenger in the CNS, and also elsewhere to regulate immune function as well. Furthermore, owing to a number of antioxidant mechanisms, melatonin therapy has been shown to protect against infections caused by both neurotropic and non-neurotropic viruses. (VEEV-Venezuelan equine encephalomyelitis Virus, HPIV3- Human Parainfluenza Virus type 3, EBOV - Ebola Virus).

Adopted from the publication (Role of Melatonin on Virus-Induced Neuropathogenesis-A Concomitant Therapeutic Strategy to Understand SARS-CoV-2 Infection; Wongchitrat P, Shukla M, Sharma R, Govitrapong P, Reiter R, 2021).

\begin{tabular}{|l|c|c|c|c|c|c|}
\hline \multicolumn{1}{|c|}{ Investigators } & Year & Virus & $\begin{array}{c}\text { Properties of } \\
\text { Melatonin }\end{array}$ & Dose of Melatonin & Effects & Reference \\
\hline Valero N., et al. & 2015 & VEEV & Antiviral effect & $0.5,1$ and $5 \mathrm{mM}$ & $\downarrow$ Virus titer in brain & {$[28]$} \\
\hline Huang SH., et al. & 2019 & $\begin{array}{c}\text { Influenza } \\
\text { A virus }\end{array}$ & Antiviral effect & $\begin{array}{c}0.1,0.25 \text { and } \\
0.5 \mathrm{mM}\end{array}$ & $\begin{array}{c}\downarrow \text { Virus titer in supernatant } \\
\text { (co-treatment with ribavirin) }\end{array}$ & {$[29]$} \\
\hline $\begin{array}{l}\text { Rabbani, M.A.G.; } \\
\text { Barik, S., et al. }\end{array}$ & 2017 & HPIV3 & Antiviral effect & $\begin{array}{c}0.05,0.25 \text { and } \\
0.49 \mathrm{mM}\end{array}$ & $\begin{array}{c}\downarrow \text { Virus titer in supernatant } \\
\text { (Co-treatment with IFN- } \gamma \text { ) }\end{array}$ \\
\hline Junaid A., et al. & 2020 & EBOV & $\begin{array}{c}\text { Protection of } \\
\text { the integrity of } \\
\text { blood vessels }\end{array}$ & $\begin{array}{c}0,0.1,1,10 \text { and } \\
100 \mu \mathrm{M} \text { for } 2 \text { hrs }\end{array}$ & $\begin{array}{l}\downarrow \text { Rho/Rock signalling } \\
{[31]}\end{array}$ \\
\hline
\end{tabular}

Table 1: Table showing effect of melatonin effect during different viral infection (In-vitro and In-vivo).

\begin{tabular}{|c|c|c|c|c|c|}
\hline Author & Year & Antioxidant & Treatment & Effect & Reference \\
\hline Cayli,SR., et al. & 2004 & Melatonin & Methylprednisolone & Reduce edema & [22] \\
\hline Adikwu, E., et al. & 2019 & & Melatonin supplement & $\begin{array}{l}\text { *Increase the effectiveness of } \\
\text { pharmacological treatment } \\
\text { *Reduce side effect of antiviral } \\
\text { drugs }\end{array}$ & {$[21]$} \\
\hline \multirow[t]{2}{*}{$\begin{array}{l}\text { Fowler, AA } 3^{\text {rd }} \text {., } \\
\text { et al. }\end{array}$} & 2019 & Ascorbic acid & $\begin{array}{l}\text { IV Vitamin C } 50 \mathrm{mg} / \mathrm{kg} \\
\text { every } 6 \text { hours for a } \\
\text { maximum of } 96 \text { hours }\end{array}$ & $\begin{array}{l}\text { Cause mortality in comparison } \\
\text { to a placebo }\end{array}$ & {$[24]$} \\
\hline & & & $\begin{array}{l}\text { High doses of IV Vitamin C } \\
(10,000-20,000 \mathrm{mg} / \text { day })\end{array}$ & $\begin{array}{l}\text { Successful treatment with large } \\
\text { dose in china on patients with } \\
\text { moderate-to-severe COVID-19 }\end{array}$ & \\
\hline \multirow[t]{2}{*}{ Fosmire GJ } & 1990 & Zinc & Regimen $40 \mathrm{mg} /$ day & Induce less human toxicity & [26] \\
\hline & & & $\begin{array}{l}\text { High dose above 200- } \\
\qquad 400 \mathrm{mg}\end{array}$ & Adverse effect nausea, vomiting & \\
\hline Lei GS & 2017 & Vitamin D & Calcitriol & $\begin{array}{l}\text { *Reduce virus infection } \\
\text { *Achieve proper it. D level in } \\
\text { COVID-19 patient }\end{array}$ & [25] \\
\hline
\end{tabular}

Table 2: Table showing effect of different antioxidants on the development of viral infections for COVID-19. 


\begin{tabular}{|c|c|c|c|c|c|}
\hline Author & Year & Antioxidant & Treatment & Effect & Reference \\
\hline $\begin{array}{l}\text { Huang S H., } \\
\text { et al. }\end{array}$ & 2019 & Melatonin & Melatonin supplement & $\begin{array}{l}\text { Decreases the production of } \\
\text { inflammatory cytokines and } \\
\text { increases the production of } \\
\text { anti-inflammatory cytokines } \\
\text { during influenza A virus } \\
\text { infection }\end{array}$ & [29] \\
\hline \multirow[t]{2}{*}{ Lai., et al. } & 2010 & $\begin{array}{l}\text { N-Acetyl-l- } \\
\text { cysteine }\end{array}$ & $\begin{array}{l}\text { NAC } 600 \mathrm{mg} \text { twice daily for } \\
6 \text { months }\end{array}$ & $\begin{array}{l}\text { *Decrease incidence and } \\
\text { severity of influenza and } \\
\text { length of bed time } \\
\text { *Inhibits viral proliferation } \\
\text { *Induction of apoptosis }\end{array}$ & {$[32]$} \\
\hline & & & $\begin{array}{c}\text { Intravenous (IV) } \\
\text { infusion of high dose NAC } \\
\text { at } 100 \mathrm{mg} / \mathrm{kg} \text { combined } \\
\text { with oseltamivir }\end{array}$ & $\begin{array}{c}\text { *Improve viral pneumonia } \\
\text { caused by H1N1 } \\
\text { *Reduced GSH displays } \\
\text { anti-influenza by inhibition of } \\
\text { viral macromolecules } \\
\text { synthesis and proliferation }\end{array}$ & \\
\hline $\begin{array}{l}\text { Kimbarowsk., } \\
\text { et al. }\end{array}$ & 1967 & Ascorbic acid & $300 \mathrm{mg} /$ day & $\begin{array}{c}* \text { Rate of pneumonia is reduced } \\
*^{*} \text { Hospital stay is reduced } \\
{ }^{*} \text { Inhibits proliferation }\end{array}$ & {$[33]$} \\
\hline Zhao., et al. & 2019 & Vitamin D & Cathelicidins & $\begin{array}{l}* \text { On non enveloped virus } \\
\text { reduce replication } \\
\text { *Reduce microbial infection }\end{array}$ & {$[34]$} \\
\hline $\begin{array}{l}\text { Ghaffari., } \\
\text { et al. }\end{array}$ & 2019 & Zinc & $\begin{array}{l}\text { Zinc oxide non a particle } \\
\text { supplementation }\end{array}$ & $\begin{array}{l}\text { *Increase CD4, CD3 cell } \\
\text { *INF production increase }\end{array}$ & [27] \\
\hline
\end{tabular}

Table 3: Table showing use of different supplementary medicines or antioxidants for influenza virus.

\section{Discussion}

Supplementary medications and antioxidant pharmaceuticals are used for more than merely avoiding deficiencies and decreasing free radical generation. Viral infections are only one of the many indicators that vitamins and antioxidants may be sufficient [35]. The pathophysiology of SARS-CoV or MERS-extremely CoV's high pathogenicity is not fully understood. Elevated levels of proinflammatory cytokines in the blood (e.g. IL1B, IL6, IL12, IFN, IP10, and MCP1) were linked to chronic inflammation and severe respiratory problems in SARS patients in early investigations [36]. Melatonin is best used in combination with an antiviral for improved COVID-19 patient recovery [37], and it may be best utilised as patients suffering from acute in COVID-19 patients. The use of melatonin in combination with antivirals like Ribavirin and Acyclovir [38] was shown to be more efficient than treatment with only the antiviral. Melatonin therapy decreases the production of inflammatory cytokines while increases the production of anti-inflammatory cytokines during influenza infection with a virus [29]. After a viral infection, researchers looked at the quantities of cytokines in the bronchoalveolar lavage fluid (BALF) of uninfected and infected mice. The inflammatory cytokines TNF- $\alpha$, IL-6, and IFN- $\gamma$ were all considerably increased by the viral infection [29]. Melatonin therapy significantly reduced TNF- $\alpha$, IL-6, and IFN-gamma production. In the BALF of experimental mice, anti-inflammatory cytokines were also assessed, and viral infection increased the production of IL-10 [30] and TGF- $\beta$ [9]. Furthermore, melatonin therapy increased the production of these cytokines much more [12]. 


\section{Conclusion}

When melatonin dosages of $3 \mathrm{mg}, 6 \mathrm{mg}$, and $10 \mathrm{mg}$ were given orally to ICU patients in clinical studies, they were shown to be safe when compared to placebo $[39,40]$. The anti-inflammation, antioxidation, and immune response modulation benefits of melatonin as an adjuvant in COVID-19 have been This review provides the first study showing that melatonin can help people with severe influenza A H1N1 virus infections. High-dose melatonin administration dramatically enhanced the lifespan of influenza A virus-infected Balb/c mice [29]. Melatonin-treated mice's BALF, on the other hand, produced significantly more IL-10. It has been established that IL-27 has a role in the production of IL-10 [41]. We looked at whether melatonin has a synergistic impact with antiviral medications Ribavirin is an RNA and DNA virus inhibitor that works against both influenza A and B viruses [42]. Such knowledge on this subject is quickly expanding, and it is presumed that this will aid in the finding of suitable vitamins and antioxidants for use in pharmacotherapy. As a result, after the end of COVID-19 Pandemic and access to effective vaccinations and supplements will contribute to improved health and social well-being [35].

\section{Bibliography}

1. Zhang R., et al. "COVID-19: Melatonin as a potential adjuvant treatment". Life Science 250 (2020): 117583.

2. Simko F., et al. "Melatonin as a putative protection against myocardial injury in COVID-19 infection". Taylor and Francis 13 (2020): 921-924.

3. Tan DX., et al. "Targeting Host Defense System and Rescuing Compromised Mitochondria to Increase Tolerance against Pathogens by Melatonin May Impact Outcome of Deadly Virus Infection Pertinent to COVID-19". Molecules 25 (2020): 4410.

4. Salles C. "Correspondence COVID-19: Melatonin as a potential adjuvant treatment". Life Sciences 253 (2020): 117716.

5. Eccles R. "Understanding the symptoms of the common cold and influenza". Lancet Infectious Diseases 5 (2005): 718-725.

6. Gambotto A., et al "Human infection with highly pathogenic H5N1 influenza virus”. Lancet 371 (2008): 1464-1475.

7. Gillim-Ross L., et al. "Emerging respiratory viruses: Challenges and vaccine strategies". Clinical Microbiology Reviews 4 (2006): 614-636.

8. Corral L., et al. "GLUCOCOVID: a controlled trial of methylprednisolone in adults hospitalized with COVID-10 pneumonia". Preprint medR $\chi i v$ (2020).
9. Reiter R J., et al. "Melatonin and its metabolites: New findings regarding their production and their radical scavenging actions". Acta Biochimica Polonica 54 (2007): 1-9.

10. Gamboa E T., et al. "Influenza virus antigen in postencephalitic parkinsonism brain. Detection by immunofluorescence". Archives of Neurology 31 (1974): 228-232.

11. Pontes GN., et al. "Pineal melatonin and the innate immune response: the TNF-alpha increase after cesarean section suppresses nocturnal melatonin production". Journal of Pineal Research 43 (2007): 365-371.

12. Chen SJ., et al. "Melatonin enhances interleukin-10 expression and suppresses chemotaxis to inhibit inflammation in situ and reduce the severity of experimental autoimmune encephalomyelitis". International Immunopharmacology 31 (2016): 169177.

13. Markus RP., et al. "Immune-pineal axis-acute inflammatory responses coordinate melatonin synthesis by pinealocytes and phagocytes". British Journal of Pharmacology 175 (2018): 3239-3250.

14. Ben-Nathan D., et al. "Protective effects of melatonin in mice infected with encephalitis viruses". Archives of Virology 140 (1995): 223-230.

15. Crespo I., et al. "Melatonin inhibits the sphingosine kinase 1/ sphingosine-1-phosphate signaling pathway in rabbits with fulminant hepatitis of viral origin". Journal of Pineal Research 61 (2016): 168-176.

16. Valero N., et al. "In vitro, melatonin treatment decreases nitric oxide levels in murine splenocytes cultured with the Venezuelan equine encephalomyelitis virus". Neurochemistry Research 30 (2005): 1439-1442.

17. Bonilla E., et al. "Melatonin increases interleukin1 $\beta$ and decreases tumor necrosis factor $\alpha$ in the brain of mice infected with the Venezuelan equine encephalomyelitis virus". Neurochemistry Research 28 (2003): 681-686.

18. Sang Y., et al. "Melatonin ameliorates coxsackievirus B3-induced myocarditis by regulating apoptosis and autophagy". Frontiers in Pharmacology 9 (2018): 1384.

19. San-Miguel B., et al. "Melatonin modulates the autophagic response in acute liver failure induced by the rabbit hemorrhagic disease virus". Journal of Pineal Research 56 (2014): 313-321. 
20. Montiel M., et al. "Melatonin decreases brain apoptosis, oxidative stress, and CD200 expression and increases survival rate in mice infected by Venezuelan equine encephalitis virus". Antiviral Chemistry and Chemotherapy 24 (2015): 99-108.

21. Adikwu E., et al. "Melatonin and alpha lipoic acid restore electrolytes and kidney morphology of lopinavir/ritonavir-treated rats". Journal of Nephropharmacology 9 (2019): e06.

22. Cayli SR., et al. "Effect of combined treatment with melatonin and methylprednisolone on neurological recovery after experimental spinal cord injury". European Spine Journal 13 (2004): 724-732.

23. Lin C., et al. "The involvement of a stress-activated pathway in equine influenza virus-mediated apoptosis". Virology 287 (2001): 202-213.

24. Fowler AA., et al. "Effect of Vitamin C infusion on organ failure and biomarkers of inflammation and vascular injury in patients with sepsis and severe acute respiratory failure: The CITRIS-ALI randomized clinical trial". JAMA 322 (2019): 12611270.

25. Lei GS., et al. "Mechanisms of Action of Vitamin D as Supplemental Therapy for Pneumocystis Pneumonia". Antimicrobial Agents and Chemotherapy 61 (2017): e01226-1317.

26. Fosmire GJ. "Zinc toxicity". The American Journal of Clinical Nutrition 51 (1990): 225-227.

27. Ghaffari H., et al. "Inhibition of H1N1 influenza virus infection by zinc oxide nanoparticles: Another emerging application of nanomedicine". Journal of Biomedical Science 26 (2019): 70.

28. Valero N., et al. "Melatonin, minocycline and ascorbic acid reduce oxidative stress and viral titers and increase survival rate in experimental Venezuelan equine encephalitis". Brain Research 1622 (2015): 368-376.

29. Huang S H., et al. "Melatonin possesses an anti-influenza potential through its immune modulatory effect". Journal of Functional Foods 58 (2019): 189-198.

30. Rabbani MAG., et al. "5-Hydroxytryptophan, a major product of tryptophan degradation, is essential for optimal replication of human parainfluenza virus". Virology 503 (2017): 46-51.

31. Junaid A., et al. "Ebola hemorrhagic shock syndrome-on-achip”. iScience 23 (2020): 100765.

32. Lai KY., et al. "High-dose N-acetylcysteine therapy for novel H1N1 influenza pneumonia". Annals of Internal Medicine 152
(2010): 687-688

33. Kimbarowski JA., et al. "Colored precipitation reaction of the urine according to Kimbarowski (FARK) as an index of the effect of ascorbic acid during treatment of viral influenza". Dtsch Gesundheitsw 22 (1967): 2413-2418.

34. Zhao Y., et al. "Vitamin D Alleviates Rotavirus Infection through a Microrna-155-5p Mediated Regulation of the TBK1/IRF3 Signaling Pathway In Vivo and In Vitro". International Journal of Molecular Sciences 20 (2019): 3562.

35. Al-Taie A., et al. "Potential Therapeutic Use of Coenzyme Q10 in Diabetes Mellitus and Its Complications: an Algorithm of Scoping Clinical Review". SN Comprehensive Clinical Medicine 3 (2021): 989-1001.

36. Wong CK., et al. "Plasma inflammatory cytokines and chemokines in severe acute respiratory syndrome". Clinical and Experimental Immunology 136 (2004): 95-103.

37. Cardinali DP., et al. "Elderly as a High-risk Group during COVID-19 Pandemic: Effect of Circadian Misalignment, Sleep Dysregulation and Melatonin Administration". Sleep and Vigilance 4 (2020): 81-87.

38. Nunes Oda S. "Regression of herpes viral infection symptoms using melatonin and SB-73: comparison with Acyclovir". Journal of Pineal Research 44 (2008): 373-378.

39. Mistraletti G., et al. "Melatonin reduces the need for sedation in ICU patients: a randomized controlled trial". Minerva Anaesthesiology 81 (2015): 1298-1310.

40. Bourne RS., et al. "Melatonin therapy to improve nocturnal sleep in critically ill patients: encouraging results from a small randomised controlled trial". Critical Care (London, England) 12 (2008): R52.

41. Fitzgerald DC., et al. "Suppression of autoimmune inflammation of the central nervous system by interleukin 10 secreted by interleukin 27-stimulated T cells". Nature Immunology 8 (2007): 1372-1379.

42. Sidwell RW., et al. "Broad-spectrum antiviral activity of Virazole: 1-beta-D-ribofuranosyl-1,2,4-triazole-3-carboxamide". Science 177 (1972): 705-706.

Volume 5 Issue 8 August 2021

(C) All rights are reserved by Seema Rai and Suman Rathore. 